\title{
Host status of cultivated plants to Meloidogyne hispanica
}

\author{
Carla Maria Nobre Maleita • Rosane Hazelmann Cunha Curtis • \\ Stephen John Powers • Isabel Abrantes
}

Accepted: 1 December 2011 / Published online: 16 December 2011

(C) The Author(s) 2011. This article is published with open access at Springerlink.com

\begin{abstract}
The reproduction of a Meloidogyne hispanica isolate from Portugal was evaluated in 63 plant species/cultivars, in pot assays at $25 \pm 2.0^{\circ} \mathrm{C}$, on the basis of root gall index (GI) and reproduction factor $(\mathrm{Rf}=$ final/initial egg density $)$ at 60 days after inoculation. Cultivars of aubergine, bean, beetroot, broccoli, carnation, corn, cucumber, French garlic, lettuce, melon, onion, parsley, pea, potato, spinach, and tobacco and two of cabbage were susceptible $(3 \leq \mathrm{GI} \leq 5 ; 1.15 \leq$ $\mathrm{Rf} \leq 262.86$ ). Cabbage cv. Bacalan, cauliflower cv. Temporão and pepper cv. Zafiro R2 were hypersusceptible or poor hosts $(\mathrm{Rf}<1$; GI $>2)$ and pepper cvs. Aurelio and Solero were resistant $(0.0 \leq \mathrm{GI} \leq 0.4$; $0.00 \leq \mathrm{Rf} \leq 0.03)$. The response of the pepper cultivars and the Mi-1 resistant tomato cv. Rossol was also conducted in pots using two inoculum levels and four temperatures, three growth chamber $\left(25 \pm 2.7^{\circ} \mathrm{C}, 29.3 \pm\right.$
\end{abstract}

C. M. N. Maleita $(\bowtie) \cdot$ I. Abrantes

IMAR - CMA, Department of Life Sciences,

University of Coimbra,

3004-517 Coimbra, Portugal

e-mail: carlamnmaleita@hotmail.com

R. H. C. Curtis

Plant Pathology and Microbiology Department,

Rothamsted Research, Harpenden,

Hertfordshire AL5 2JQ, UK

S. J. Powers

Biomathematics and Bioinformatics Department,

Rothamsted Research, Harpenden,

Hertfordshire AL5 2JQ, UK $1.8^{\circ} \mathrm{C}$ and $\left.33.6 \pm 1.2^{\circ} \mathrm{C}\right)$ and one outdoors $\left(24.4 \pm 8.2^{\circ} \mathrm{C}\right)$. At $24.4 \pm 8.2^{\circ} \mathrm{C}$ and $25 \pm 2.7^{\circ} \mathrm{C}$, the reproduction on the resistant tomato was significantly lower compared to the susceptible cv. Easypeel. At all temperatures, resistance was evident for the pepper cultivars, despite the fact they were not found to contain any of the $\mathrm{Mel}, \mathrm{Me} 3, \mathrm{Me} 7$ and

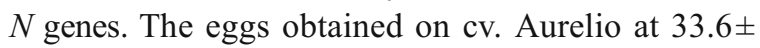
$1.2^{\circ} \mathrm{C}$ were used to get a selected resistance breaking isolate of $M$. hispanica that was able to reproduce on the three pepper cultivars. Our results suggest that the initial $M$. hispanica isolate is a mixture of virulent and avirulent individuals. The pepper cultivars tested, have potential to reduce $M$. hispanica populations in agro-ecosystems under certain conditions, but they should be used as a part of an integrated management strategy in order to prevent the development of virulent populations.

Keywords Host range $\cdot M e$ genes $\cdot N$ gene .

Pathogenicity $\cdot$ Pepper $\cdot$ Root-knot nematodes

\section{Introduction}

Meloidogyne hispanica Hirschmann, 1986 was described for the first time in Seville, Spain on a peach rootstock (Prunus persica silvestris Batsch) and later detected in other areas of the country on beet (Beta vulgaris L.) and grapevines and found also to reproduce on wheat (Triticum aestivum L.) in greenhouse conditions (Karssen and van Hoenselaar 1998; Castillo 
et al. 2009). It has been also found in South Africa, Brazil, Australia, Burkina Faso, Malawi, Martinique, The Netherlands, Cape Verde Islands, Fiji Islands, France, Korea, Puerto Rico and United States alone or in mixed populations with other Meloidogyne species and in association with several plant species as sugar cane, snapdragon, Amaranthus sp., Pelargonium notatum, Ficus sp., squash plants, grapevine, tomato, banana, cucumber and sweet pepper (Esbenshade and Triantaphyllou 1985; Fargette 1987; Kleynhans 1993; Hugall et al. 1994; Trudgill et al. 2000; Carneiro et al. 2004; Karssen 2004; Cofcewicz et al. 2005; Chaves et al. 2007; van der Wurff et al. 2010).

In Portugal, the nematode was found parasitizing roots of fig-trees (Ficus carica L.), and carnation (Dianthus caryophyllus L.) and has been reported alone or in association with M. javanica in potato (Solanum tuberosum L.) fields (Abrantes et al. 2008; Landa et al. 2008; Conceição et al. 2009). In a previous study, melon (Cucumis sativus L.) cvs Gazver and Jazzer, bean (Phasealus vulgaris L.) cvs Foicinha and Rajado, corn (Zea mays L.) cvs Belgrano and PR35P12, tomato (S. lycopersicum L.) cvs Roma, Rutgers and Sinatra, and potato cvs Baraka and Diana, were rated as susceptible to $M$. hispanica. Furthermore, lettuce (Lactuca sativa L.) cvs Apulia and Esperie and tomato Viriato F1 exhibited galls but did not support nematode reproduction while the pepper $\mathrm{cv}$. Galileo was resistant (Maleita et al. 2005).

Root-knot nematodes (RKN) are usually controlled by applying nematicides, but these are being phased out due to their harmful effects on human health and the environment (Wesemael et al. 2011). Crop rotation, including non-host or resistant species, can be effective to reduce Meloidogyne spp. infections, but to be successful, it is important to know the host status of a large number of crops and cultivars.

In pepper, the $N$ gene confers dominant resistance to $M$. arenaria, $M$. incognita and $M$. javanica, but its efficacy is variable depending on the nematode isolate and inoculum level. This gene was found in the cv. Mississipi Nemaheart and was introgressed into two pepper cultivars, thus developing two resistant lines: Carolina Wonder and Charleston Bell (Thies et al. 2008). Nine additional resistant genes (Mel to $\mathrm{Me} 7$, Mech1 and Mech2) were identified in pepper accessions PM217, PM687, PM702, DH330 and Yolo Wonder (Wang and Bosland 2006; Djian-Caporalino et al. 2007). The Mel and $M e 3$ genes confer partial resistance while $M e 7$ gene complete resistance to $M$. arenaria, $M$. incognita and $M$. javanica; the $M e 2$ gene confers resistance to $M$. hispanica and M. javanica; the Me4 and Me5 genes confer resistance to M. arenaria; the Me6 gene confers resistance to $M$. arenaria and M. javanica (French population) and the Mech1 and Mech2 genes confer resistance to M. chitwoodi (Wang and Bosland 2006; Djian-Caporalino et al. 2007). The $M e$ and $N$ resistance genes in pepper, in contrast to the $M i$ gene in tomato, have been shown to be heat-stable resistance genes, an advantage in tropical, sub-tropical and warm temperate areas (DjianCaporalino et al. 2007; Thies et al. 2008).

The objectives of the work described here were: 1 ) to evaluate the host suitability of several cultivated plants to $M$. hispanica; 2) to determine the effects of temperature and initial population densities on nematode reproduction in three commercially pepper cultivars (Aurelio, Solero and Zafiro R2); and 3) to assess the presence/absence of the $\mathrm{Me1}, \mathrm{Me} 3, \mathrm{Me} 7$ and $\mathrm{N}$ resistance genes in these pepper cultivars (with the four pepper accessions Yolo Wonder, Doux Long des Landes, DH149 and DH330 used as controls) by DNA amplification, using specific markers as a sequencecharacterized amplified region (SCAR).

\section{Material and methods}

Nematode isolate

The M. hispanica isolate, originally obtained from infected fig tree roots collected in Odeceixe, Faro, Portugal, was maintained on tomato, S. lycopersicum, cv. Easypeel, in pots containing sterilized sandy loam soil and sand (1:1), in the Nematology Laboratory at University of Coimbra, Portugal. The species identification was confirmed by esterase phenotype analysis (Abrantes et al. 2008).

Host status of cultivated plants

The response of 63 commercial plant species/cultivars (Table 1), comprising 18 plant species and representing 10 botanical families, to $M$. hispanica was evaluated under controlled conditions. Cultivars of bean, corn, cucumber, lettuce, melon, pepper and tomato were grown from seeds. Four-week old seedlings were transplanted into $10 \mathrm{~cm}$-diameter pots filled with a 
mixture (1:1) of sterilized sandy loam soil and sand. Potato plants were grown from single sprouts in pots with $500 \mathrm{~cm}^{3}$ of sterilized sandy loam soil and sand (1:2). Seedlings of the remaining plant species and cultivars were obtained from a nursery (Germiplanta -Viveiros de Plantas Lda., Portugal) and transplanted into $10 \mathrm{~cm}$-diameter pots as stated before.

The nematode inoculum was obtained by extraction of eggs from infected tomato roots, using $0.52 \%$ sodium hypochlorite $(\mathrm{NaOCl})$ solution (Hussey and Barker 1973). Five plants from each plant species/cultivar were inoculated with 5,000 eggs ( $\mathrm{Pi}$, initial population density) to evaluate host suitability (Sasser et al. 1984). The tomato cv. Easypeel served as positive control while non inoculated plants of each cultivar were used as negative controls. The pots were arranged in a completely randomized design in a growth chamber, at $25 \pm 2^{\circ} \mathrm{C}$, with a $12 \mathrm{~h}$ photoperiod and $70-75 \%$ relative humidity. Plants were watered daily and fertilized weekly with Hyponex ${ }^{\circledR}$ (The Hiponex Co., Inc., Copley Ohio, USA), a water soluble fertilizer (7\% N, 6\% P and 19\% K).

At 60 days after inoculation, the plants were harvested, the root systems washed carefully and rated for galls according to a scale of 0 to $5(0=$ no galls, $1=1-2$, $2=3-10,3=11-30,4=31-100,5>100$ galls) (Taylor and Sasser 1978). Eggs from the whole root system were extracted as described above, counted to determine the final population density (Pf) and the reproduction factor $(\mathrm{Rf}=\mathrm{Pf} / \mathrm{Pi})$ was calculated. Host suitability was assessed on the basis of root gall index (GI), an indicator of plant damage and $\mathrm{Rf}$ as an indicator of nematode reproduction or host efficiency. Therefore, plants with GI $>2$ and $\mathrm{Rf}>1$ were considered susceptible, with $\mathrm{GI}>2$ and $\mathrm{Rf} \leq 1$ hypersusceptible, with $\mathrm{GI} \leq 2$ and $\mathrm{Rf} \leq 1$ resistant and with $\mathrm{GI} \leq 2$ and Rf $>1$ tolerant (Sasser et al. 1984). Roots of plant species/cultivars which were considered as resistant were stained with acid fuchsin and examined at the stereomicroscope to determine the degree of nematode development (Byrd et al. 1983).

Effect of inoculum level and temperature on reproduction of $M$. hispanica on pepper

The pepper cultivars Aurelio, Solero and Zafiro R2 (Table 1) were used to evaluate the influence of two initial inoculum densities combined with different temperatures regimes on the reproduction of $M$. hispanica. Four-week old seedlings were transplanted into $10 \mathrm{~cm}$-diameter pots filled with a mixture $(1: 1)$ of sterilized sandy loam soil and sand. Five plants of each pepper cultivar were inoculated with 2,500 or 5,000 eggs (Pi) and maintained in growth chambers at $25 \pm$ $2.7^{\circ} \mathrm{C}, 29.3 \pm 1.8^{\circ} \mathrm{C}$ or $33.6 \pm 1.2^{\circ} \mathrm{C}$, or exposed outdoors during summer (July and August, $24.4 \pm 8.2^{\circ} \mathrm{C}$ ), in a completely randomized design. The nematode had a shorter life cycle at $30^{\circ} \mathrm{C}$ than at $25^{\circ} \mathrm{C}$ and at $35^{\circ} \mathrm{C}$ the completion of the life cycle was inhibited (Maleita et al. 2011a). The tomato cv. Easypeel, highly susceptible to the nematode, was used as a positive control, and the Mi-1 resistant tomato $\mathrm{cv}$. Rossol, for evaluating the effect of temperature on the efficiency of the Mi-1 gene. Also, non inoculated plants served as negative controls. Sixty days after nematode inoculation, the plants were uprooted and evaluated for GI and Rf as described in the previous section.

Meloidogyne hispanica eggs obtained from cv. Aurelio, in the test conducted at $33.6 \pm 1.2^{\circ} \mathrm{C}$, were further used to increase the selected $M$. hispanica isolate in the same pepper cultivar by two successive transfers (two months each), equal to development of four generations, at $25 \pm 2^{\circ} \mathrm{C}$. Then, five four-week-old plants from each of pepper cultivars Aurelio, Solero and Zafiro R2 and of tomato cv. Easypeel were inoculated with 5,000 eggs of the selected M. hispanica isolate. Experimental conditions, plant maintenance and assessment of the responses were as described above for the host status experiment. The species identification of this new isolate was also confirmed by esterase phenotype (Abrantes et al. 2008).

Assessment for the presence of $\mathrm{Me1}, \mathrm{Me} 3, \mathrm{Me} 7$ and $\mathrm{N}$ genes in the pepper cultivars

The pepper accessions Yolo Wonder and Doux Long des Landes, lacking the RKN resistance genes Mel, $M e 3, M e 7$ and $N$, and the double haploid pepper lines DH149 and DH330, carrying the Me3 and Mel genes, respectively, were included in this assessment as controls, while there was no positive control for the $N$ gene. Plant DNA extraction was performed as described by Zhang et al. (1998) with some modifications from leaf tissue, except for the accession DH330 that was extracted from seeds, due to difficulties in seed germination. Four leaf discs per each pepper cultivar were collected by opening and closing the lid of a sterile Eppendorf tube, to pinch leaf discs 
Table 1 Host status of cultivated plants to the root-knot nematode Meloidogyne hispanica, 60 days after inoculation with 5,000 eggs per plant in a pot experiment conducted in a growth chamber

\begin{tabular}{|c|c|c|c|c|c|}
\hline $\begin{array}{l}\text { Family } \\
\text { Plant species (common name) }\end{array}$ & Cultivar & $\mathrm{GI}^{\mathrm{a}}$ & $\mathrm{Pf}^{\mathrm{b}}$ & $\mathrm{Rf}^{\mathrm{c}}$ & $\begin{array}{l}\text { Host } \\
\text { status }^{d}\end{array}$ \\
\hline \multicolumn{6}{|l|}{ Alliaceae } \\
\hline Allium sp. (French garlic) & Lancelot & 3.6 & $6228 \pm 4292 a-i, n-q$ & 1.25 & S \\
\hline \multirow[t]{2}{*}{ Allium cepa L. (Onion) } & $10044^{*}$ & 4.5 & $31292 \pm 18684 a-q$ & 6.26 & S \\
\hline & Canataxique & 4.2 & $22704 \pm 13$ 336a-q & 4.54 & S \\
\hline \multicolumn{6}{|l|}{ Apiaceae } \\
\hline $\begin{array}{l}\text { Petroselinum crispum (P.Mill.) } \\
\text { Nyman ex A.W.Hill (Parsley) } \\
\text { Asteraceae }\end{array}$ & (Unknown) & 5.0 & $44193 \pm 31247 a-q$ & 8.84 & S \\
\hline \multirow[t]{5}{*}{ Lactuca sativa L. (Lettuce) } & $\operatorname{Irazu}^{* *}$ & 4.0 & $63267 \pm 55823 \mathrm{a}-\mathrm{q}$ & 12.65 & S \\
\hline & Rolina & 4.0 & $53000 \pm 38240 a-q$ & 10.60 & S \\
\hline & Esperie & 5.0 & $15683 \pm 2964 a-q$ & 3.14 & S \\
\hline & Invicta & 4.0 & $15290 \pm 5272 a-q$ & 3.06 & S \\
\hline & Afiction & 4.0 & $13269 \pm 7814 \mathrm{a}-\mathrm{i}, \mathrm{k}-\mathrm{q}$ & 2.65 & $\mathrm{~S}$ \\
\hline \multicolumn{6}{|l|}{ Brassicaceae (Cruciferae) } \\
\hline Brassica oleracea L. var. botrytis (Cauliflower) & Temporão & 5.0 & $2328 \pm 871 \mathrm{a}-\mathrm{i}, \mathrm{o}-\mathrm{q}$ & 0.47 & HS \\
\hline \multirow[t]{3}{*}{ Brassica oleracea L. var. capitata (Cabbage) } & Tronchuda Portuguesa & 5.0 & $15367 \pm 2805 a-q$ & 3.07 & $\mathrm{~S}$ \\
\hline & Coração de boi & 5.0 & $14880 \pm 7981 \mathrm{a}-\mathrm{q}$ & 2.98 & S \\
\hline & Bacalan & 5.0 & $2207 \pm 1874 \mathrm{a}-\mathrm{i}, \mathrm{o}-\mathrm{q}$ & 0.44 & HS \\
\hline Brassica oleracea L. var. italica (Broccoli) & Verde & 5.0 & $6923 \pm 3439 a-i, n-q$ & 1.38 & S \\
\hline \multicolumn{6}{|l|}{ Caryophyllaceae } \\
\hline Dianthus caryophyllus L. (Carnation) & (Unknown) & 5.0 & $11390 \pm 4$ 754a-i, m-q & 2.28 & S \\
\hline \multicolumn{6}{|l|}{ Chenopodiaceae } \\
\hline Beta vulgaris L. (Beetroot) & (Unknown) & 3.8 & $5773 \pm 2481 a-i, n-q$ & 1.15 & S \\
\hline Spinacia oleracea L. (Spinach) & (Unknown) & 5.0 & $37933 \pm 10771 \mathrm{a}-\mathrm{q}$ & 7.59 & S \\
\hline \multicolumn{6}{|l|}{ Cucurbitaceae } \\
\hline \multirow[t]{2}{*}{ Cucumis melo L. (Melon) } & Fiesta & 5.0 & $216480 \pm 68212 a-q$ & 43.30 & S \\
\hline & Branco Ribatejo & 5.0 & $20920 \pm 4$ 551a-q & 4.18 & S \\
\hline \multirow[t]{2}{*}{ Cucumis sativus L. (Cucumber) } & Inglês Comprido & 5.0 & $147080 \pm 58651 \mathrm{a}-\mathrm{q}$ & 29.42 & S \\
\hline & Longo da China** & 5.0 & $141467 \pm 124439 a-q$ & 28.29 & S \\
\hline \multicolumn{6}{|l|}{ Fabaceae } \\
\hline \multirow[t]{3}{*}{ Phaseolus vulgaris L. (Bean) } & Bencanta Trepar & 5.0 & $512520 \pm 153370 a-q$ & 102.50 & S \\
\hline & Judia* & 5.0 & $234133 \pm 72849 \mathrm{a}-\mathrm{q}$ & 46.83 & S \\
\hline & Helda & 5.0 & $205093 \pm 132174 a-q$ & 41.02 & S \\
\hline \multirow[t]{2}{*}{ Pisum sativum L. (Pea) } & Progresso 9 & 5.0 & $625920 \pm 249344 a-q$ & 125.18 & S \\
\hline & Rondo & 5.0 & $370280 \pm 97383 a-q$ & 74.06 & S \\
\hline \multicolumn{6}{|l|}{ Poaceae } \\
\hline \multirow[t]{12}{*}{ Zea mays L. (Corn) } & PR34N43* & 5.0 & $267900 \pm 32142 a-q$ & 53.58 & S \\
\hline & Lambada & 5.0 & $169733 \pm 76$ 882a-g, j-q & 33.95 & S \\
\hline & PR34B23 & 5.0 & $160240 \pm 35667 a-q$ & 32.05 & S \\
\hline & PR39T84 & 5.0 & $138893 \pm 62094 a-q$ & 27.78 & S \\
\hline & PR33Y56 & 5.0 & $137600 \pm 39943 a-q$ & 27.52 & S \\
\hline & PR33A46 & 5.0 & $132440 \pm 70047 \mathrm{a}-\mathrm{q}$ & 26.49 & S \\
\hline & PR36Y03 & 5.0 & $125680 \pm 23803 a-q$ & 25.14 & S \\
\hline & PR33N09 & 5.0 & $98773 \pm 25313 a-q$ & 19.75 & S \\
\hline & PR36R10** & 4.0 & $29233 \pm 15922 a-q$ & 5.85 & S \\
\hline & PR34G13 & 4.0 & $28780 \pm 8747 a-q$ & 5.76 & S \\
\hline & PR36B08* & 3.0 & $17871 \pm 11789 a-q$ & 3.57 & S \\
\hline & PR38R92 & 5.0 & $14375 \pm 11695 a-i, k-q$ & 2.88 & S \\
\hline
\end{tabular}


Table 1 (continued)

\begin{tabular}{|c|c|c|c|c|c|}
\hline $\begin{array}{l}\text { Family } \\
\text { Plant species (common name) }\end{array}$ & Cultivar & $\mathrm{GI}^{\mathrm{a}}$ & $\mathrm{Pf}^{\mathrm{b}}$ & $\mathrm{Rf}^{\mathrm{c}}$ & $\begin{array}{l}\text { Host } \\
\text { status }^{d}\end{array}$ \\
\hline \multicolumn{6}{|l|}{ Solanaceae } \\
\hline \multirow[t]{3}{*}{ Capsicum annuum L. (Pepper) } & Zafiro R2 & 2.4 & $1238 \pm 862 \mathrm{a}-\mathrm{i}, \mathrm{p}-\mathrm{q}$ & 0.25 & HS \\
\hline & Aurelio & 0.4 & $153 \pm 221 \mathrm{a}-\mathrm{i}, \mathrm{q}$ & 0.03 & $\mathrm{R}$ \\
\hline & Solero & 0.0 & $0.00 \pm 0.00 \mathrm{a}-\mathrm{i}$ & 0.00 & $\mathrm{R}$ \\
\hline Nicotiana tabacum L. (Tobacco) & (Unknown) & 4.0 & $12343 \pm 6796 a-i, 1-q$ & 2.47 & $\mathrm{~S}$ \\
\hline Solanum lycopersicum L. (Tomato) & Easypeel & 5.0 & $362080 \pm 44699 a-q$ & 72.42 & $\mathrm{~S}$ \\
\hline Solanum melongena L. (Aubergine) & (Unknown) & 5.0 & $77560 \pm 34109 a-q$ & 15.51 & $\mathrm{~S}$ \\
\hline \multirow[t]{19}{*}{ Solanum tuberosum L. (Potato) } & Vivaldi & 5.0 & $1314307 \pm 144312 a, j-q$ & 262.86 & $\mathrm{~S}$ \\
\hline & Latona & 5.0 & $1224973 \pm 119409 a, b, j-q$ & 244.99 & $\mathrm{~S}$ \\
\hline & Agria & 5.0 & $1160400 \pm 217046 a-c, j-q$ & 232.08 & $\mathrm{~S}$ \\
\hline & Adora & 5.0 & $1015200 \pm 161033 a-d, j-q$ & 203.04 & $\mathrm{~S}$ \\
\hline & Picasso & 5.0 & $804120 \pm 393967 a-e, j-q$ & 160.82 & $\mathrm{~S}$ \\
\hline & Jaerla* & 5.0 & $716867 \pm 342$ 187a-h, j-q & 143.37 & $\mathrm{~S}$ \\
\hline & Red Scarlet & 5.0 & $694640 \pm 194$ 175a-e, j-q & 138.93 & $\mathrm{~S}$ \\
\hline & Sifra & 5.0 & $673440 \pm 101789 a-e$, j-q & 134.69 & $\mathrm{~S}$ \\
\hline & Monalisa & 5.0 & $586373 \pm 39479 a-f$, j-q & 117.27 & $\mathrm{~S}$ \\
\hline & Sylvana & 5.0 & $584400 \pm 142530 a-g, j-q$ & 116.88 & $\mathrm{~S}$ \\
\hline & Bartina & 5.0 & $551280 \pm 290098 \mathrm{a}-\mathrm{q}$ & 110.26 & $\mathrm{~S}$ \\
\hline & Innovator & 5.0 & $535200 \pm 110145 a-h, j-q$ & 107.04 & $\mathrm{~S}$ \\
\hline & Arrow* & 5.0 & $510300 \pm 171412 \mathrm{a}-\mathrm{q}$ & 102.06 & $\mathrm{~S}$ \\
\hline & Marfona & 5.0 & $509520 \pm 48830 a-q$ & 101.90 & $\mathrm{~S}$ \\
\hline & Carrera & 5.0 & $496560 \pm 149079 a-q$ & 99.31 & $\mathrm{~S}$ \\
\hline & Pekaro & 5.0 & $474000 \pm 340495 a-q$ & 94.80 & $\mathrm{~S}$ \\
\hline & Kondor & 5.0 & $459360 \pm 227325 a-q$ & 91.87 & $\mathrm{~S}$ \\
\hline & Red Baron & 5.0 & $438267 \pm 201523 a-q$ & 87.65 & $\mathrm{~S}$ \\
\hline & Asterix & 5.0 & $433440 \pm 100041 \mathrm{a}-\mathrm{q}$ & 86.69 & $\mathrm{~S}$ \\
\hline
\end{tabular}

${ }^{\mathrm{a}} \mathrm{GI}=$ Gall Index (scale 0-5): $0=$ no galls, $1=1-2,2=3-10,3=11-30,4=31-100,5>100$ galls per root system

${ }^{\mathrm{b}} \mathrm{Pf}=$ final population density

Data are means of three **, four * or five (all other cultivars) replicates \pm standard deviation. Means in this column followed by the same combination of letters do not differ significantly at $P>0.05$, according to the Kruskal-Wallis test

${ }^{\mathrm{c}} \operatorname{Rf}$ (reproduction factor) $=\mathrm{Pf} /$ initial inoculum

${ }^{\mathrm{d}}$ Host status category: $\mathrm{R}=$ resistant $(\mathrm{Rf} \leq 1$ and $\mathrm{GI} \leq 2)$; $\mathrm{HS}=$ hypersusceptible $(\mathrm{Rf} \leq 1$ and $\mathrm{GI}>2) ; \mathrm{S}=$ susceptible $(\mathrm{Rf}>1$ and $\mathrm{GI}>2)$

directly into the tube. For the accession DH330, the seeds were soaked for $1 \mathrm{~h}$ in sterilized distilled water, the seed coat removed, and the embryo and endosperm transferred to a sterile Eppendorf tube. The tubes with leaf or seed samples were then immersed in liquid nitrogen. The tissues were macerated using a pestle and mixed with $800 \mu \mathrm{l}$ of cetyltrimethylammonium bromide (CTAB) buffer ( $\%$ CTAB, $1.4 \mathrm{M} \mathrm{NaCl}, 20$ mM EDTA, $100 \mathrm{mM}$ Tris-HCl pH 8.0 and $0.2 \%$ mercaptoethanol) at $60^{\circ} \mathrm{C}$. The mixtures were maintained at $60^{\circ} \mathrm{C}$ in a water-bath for $20 \mathrm{~min}$ and during the incubation, they were briefly vortexed several times. After the incubation, $600 \mu \mathrm{l}$ of phenol:chloroform:isoamyl alchohol (25:24:1) was added and mixed by vortexing. The extract was centrifuged at $15,441 \times \mathrm{g}$ for $5 \mathrm{~min}$ and the supernatant, having been transferred to a new Eppendorf tube, was mixed with an equal volume of isopropanol, left in ice for $10 \mathrm{~min}$ and centrifuged at $15,441 \times \mathrm{g}$ for $8 \mathrm{~min}$ to remove the aqueous phase. The precipitated DNA was washed in $500 \mu$ of $70 \%$ ethanol, the pellet dried at $40^{\circ} \mathrm{C}$ for $10 \mathrm{~min}$ and dissolved in $50 \mu \mathrm{l}$ of sterilized distilled water. 
Amplification of the markers linked to the $\mathrm{Mel}$ and $\mathrm{Me} 7$ genes and $\mathrm{Me} 3$ gene as a SCAR was carried out as described by Djian-Caporalino et al. (2007), using the primers $\mathrm{CD}$ forward (5'-GAA GCT TAT GTG GTA MCC-3') and reverse (5'-GCA AAG TAA TTA TAT GCA AGA GT-3') and B94 forward (5'- GCT TAT CAT GGC TAG TAG GG-3') and reverse (5'CGG ACC ATA CTG GGA CGA TC-3'), respectively. Amplification of the marker linked to the $N$ gene as a SCAR (forward 5'-AAT TCA GAA AAA GAC TTG GAA GG-3' and reverse 5'-TAA AGG GAT TCA TTT TAT GCA TAC-3') was carried out as described by Wang et al. (2009). The PCR products were analysed on $1.5-3 \%$ agarose gels for $\mathrm{Me} 1, \mathrm{Me} 7$ and $\mathrm{Me} 3$ genes, or on a $15 \%$ polyacrylamide gel in $1 \times$ TBE buffer for the $N$ gene, stained with ethidium bromide.

An evaluation for the presence/absence of the $M e 2$, $\mathrm{Me} 4, \mathrm{Me} 5$ and $\mathrm{Me} 6$ resistance genes in these cultivars has been impossible due to the lack of specific molecular markers.

\section{Data analysis}

A few plants died before the end of the host status experiment (Table 1), so one replicate was missing for onion (cv 10044), potato (cvs Arrow and Jaerla), bean (cv Judia) and corn (cvs PR34N43 and PR36B08) while two replicates were missing for lettuce (cv Irazu), cucumber (cv Longo da China) and corn (cv PR36R10). Data (Pf) on host status of cultivated plants were checked for evidence of a Normal distribution using the Kolmogorov-Smirnov test, and for variance homogeneity using Levene's test and were found to violate these two assumptions of analysis of variance (ANOVA), even after transformations (logarithm and square root). The non-parametric Kruskal-Wallis test was therefore performed to test for differences among the plant species and cultivars. Statistical analysis of the Pf data was performed using Statsoft Statistica version 7 for Windows.

Statistical analysis of data from the experiment, considering the effect of inoculum levels and temperature on nematode reproduction in three pepper cultivars, was performed using GenStat ${ }^{\circledR}\left[2009,12^{\text {th }}\right.$ edition, CLawes Agricultural Trust (Rothamsted Research), VSN International Ltd, Hemel Hempstead, UK]. For this analysis, a square root transformation of the data was used to ensure a Normal distribution and constant variance, as checked by plotting the residuals against the fitted values from the ANOVA. Following ANOVA, least significant difference (LSD) values were used to separate the means of combinations of inoculum level of $M$. hispanica, cultivar and temperature, at $5 \%$ level of significance. The Pf data for the new isolate of $M$. hispanica selected in cv. Aurelio and subsequently assessed in the three pepper cultivars and tomato cv. Easypeel, were analysed using the Kruskal-Wallis approach as these data also violated the ANOVA assumptions.

\section{Results}

Host status of cultivated plants

Plant species and cultivars varied in their responses to $M$. hispanica and variation in the final population density was high among replicates. Meloidogyne hispanica reproduced ( $\mathrm{Rf}>1)$ on 58 of the 63 plant species and cultivars, being classified as susceptible: aubergine; three cvs of bean; beetroot; one cv. of broccoli; two cvs of cabbage; carnation; twelve cvs of corn; two cvs of cucumber; one cv. of French garlic; five cvs of lettuce; two cvs of melon; two cvs of onion; parsley; two cvs of pea; nineteen cvs of potato; spinach; tobacco and the tomato used as a control (Table 1). In pepper cv. Zafiro R2, cauliflower cv. Temporão and cabbage cv. Bacalan, the nematode induced galls on roots (GI $>2$ ) and a small number of eggs were produced with Rf values varying from 0.25 (pepper cv. Zafiro R2) to 0.47 (cauliflower cv. Temporão) (Table 1). The cauliflower cv. Temporão and cabbage cv. Bacalan each presented more than 100 galls per plant and an average of 46.40 and 28.80 egg masses (EM), respectively. Pepper cv. Zafiro R2 had a lower number of galls (11.0) and of egg masses (11.4) per plant. Pepper cvs Aurelio and Solero were resistant to M. hispanica $(0.0 \leq$ $\mathrm{GI} \leq 0.4 ; 0.0 \leq \mathrm{Rf} \leq 0.03$ ) (Table 1 ). In these pepper cultivars penetration of $\mathrm{J} 2$ and cell necrosis around the nematode lip region were observed in stained roots, and only a reduced number of nematodes were able to establish a feeding site and complete the life cycle in cv. Aurelio (EM=0.4, Pf=153 \pm 221$)$. Tomato cv. Easypeel, used as a control, was highly infected by $M$. hispanica with $\mathrm{GI}=5$ and $\mathrm{Rf}=72.42$ (Table 1 ). The non inoculated plants were not galled.

The Pf across plant species and cultivars indicated that the most susceptible hosts were (in decreasing 
order of susceptibility): eight potato cultivars (cvs Vivaldi, Latona, Agria, Adora, Picasso, Jaerla, Red Scarlet and Safira) $>$ pea (cv. Progresso 9) $>$ four potato cultivars (cvs Monalisa, Sylvana, Bartina and Innovator). The resistant and the least susceptible hosts were (in decreasing order of susceptibility) corn (cv. PR38R92) $>$ lettuce $(\mathrm{cv}$. Afiction $)>$ tobacco $>$ carnation $>$ broccoli $(\mathrm{cv}$. Verde) $>$ French garlic $(\mathrm{cv}$. Lancelot $)>$ beetroot $>$ cauliflower (cv. Temporão) $>$ cabbage $(\mathrm{cv}$. Bacalan) $>$ three pepper cultivars (cvs Zafiro R2, Aurelio and Solero). All the other plant species/cultivars outside these two groups did not differ statistically from each other $(P>0.05$, Table 1$)$.

Effect of inoculum level and temperature on reproduction of $M$. hispanica on pepper

The response of the nematode varied across the pepper (Aurelio, Solero and Zafiro R2) and tomato (Easypeel and Rossol) cultivars with respect to initial inoculum level and temperature, as indicated by significant cultivar $\mathrm{x}$ inoculum $\mathrm{x}$ temperature interaction for Pf values $(P<0.001$, Table 2$)$. For the $M i-1$ resistant tomato $\mathrm{cv}$. Rossol, the GI and Rf values were greater than or equal to 4.0 and 5.42, respectively, at the two inoculum levels and at all temperatures. The greatest Pf was observed for tomato cv. Easypeel in the treatment in which the pots were exposed to outdoor conditions. In controlled conditions, this cultivar showed the greatest Pf value at $25^{\circ} \mathrm{C}$. However, cv. Rossol showed the greatest $\mathrm{Pf}$ in controlled conditions at $29.3^{\circ} \mathrm{C}$ when inoculated with 5,000 eggs $(\mathrm{Pf}=295$ 813), and nematode reproduction was significantly lower from $\mathrm{cv}$. Easypeel $(P \leq 0.05$, Table 2$)$. At $33.6^{\circ} \mathrm{C}$, tomato $\mathrm{cv}$. Easypeel plants died before the end of the experiment. Significant differences were observed in the Pf of $M$. hispanica produced for each of the tomato cultivars between the two inocula $(P \leq 0.05)$, except for $\mathrm{cv}$. Rossol exposed to outdoor temperatures and at $25^{\circ} \mathrm{C}$ for cv. Easypeel. The pepper cultivars were largely resistant at all temperatures, and no differences were detected in Pf of $M$. hispanica among pepper cultivars at each temperature $(P>0.05)$ and the two inoculum densities (Table 2).

When the selected M. hispanica isolate from $\mathrm{cv}$. Aurelio at $33.6^{\circ} \mathrm{C}$ was used to inoculate the three pepper cultivars, the $\mathrm{Rf}$ values ranged from 11.57 on cv. Zafiro R2 to 21.42 on cv. Solero, and all showed GI=5 (Table 3). Cultivars Aurelio and Solero had slightly higher Pf values than cv. Zafiro R2, but the difference was not significant $(P>0.05)$. However, cv. Zafiro R2 had Pf values significantly lower $(P \leq 0.05)$ than the tomato cv. Easypeel, used as a control. No differences were observed between the Pf of M. hispanica on pepper cvs Aurelio and Solero and tomato cv. Easypeel (Table 3). These pepper cultivars, found to be hosts of the selected M. hispanica isolate in this experiment (Table 3), had been previously considered as hypersusceptible or resistant (Tables 1 and 2).

Assessment for the presence of $\mathrm{Mel}, \mathrm{Me} 3, \mathrm{Me} 7$ and $\mathrm{N}$ genes in the pepper cultivars

Amplification of SCAR_CD using DNA from pepper cvs Aurelio, Solero, Zafiro R2, Doux Long des Landes and Yolo Wonder resulted in a single DNA fragment of approximately $160 \mathrm{bp}$, indicating the absence of the $\mathrm{Mel}$ and $\mathrm{Me} 7$ genes. Amplified DNA from pepper DH330, used as a positive control of the Mel gene, displayed two bands, a weak band of approximately $160 \mathrm{bp}$ and a strong band of approximately $100 \mathrm{bp}$ confirming the presence of the gene (Fig. 1). Amplification of the SCAR_B94 marker presented a band of approximately $240 \mathrm{bp}$, for the pepper accession DH149, indicating the presence of the $M e 3$ gene, and a band of approximately $220 \mathrm{bp}$ for the remaining pepper cultivars, indicating the absence of this gene in all of them (Fig. 1). Amplification of the SCAR marker linked to the $N$ gene resulted in a band of approximately $330 \mathrm{bp}$ in the three pepper cultivars Solero, Zafiro R2 and Aurelio tested and in the cultivars used as negative controls (cvs Doux Long des Landes and Yolo Wonder), indicating the absence of this gene (Fig. 2).

\section{Discussion}

Fifty eight of the 63 plant species and cultivars were found to be susceptible or good $(\mathrm{Rf}=1.1-5.0)$ and excellent ( $\mathrm{Rf}>5.0$ ) hosts (Sasser et al. 1984; Ibrahim et al. 1993) for M. hispanica. The host range of $M$. hispanica includes the families Alliaceae, Apiaceae, Asteraceae, Brassicaceae, Caryophyllaceae, Chenopodiaceae, Cucurbitaceae, Fabaceae, Poaceae and Solanaceae. Although substantial differences occurred among the various plant species and cultivars related to the host suitability parameters measured, only the 


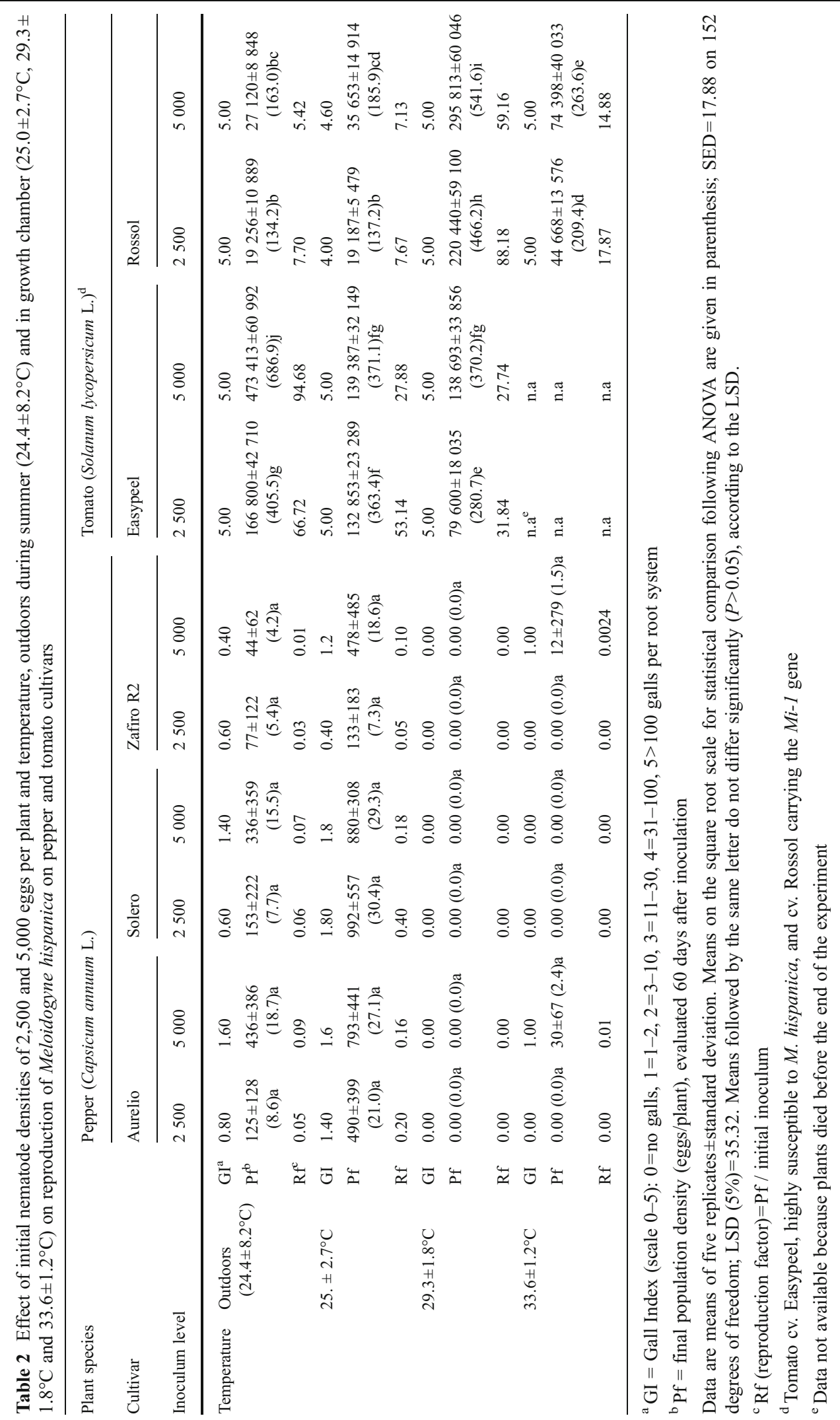


Table 3 Reproduction of a Meloidogyne hispanica isolate, previously selected on the pepper cv. Aurelio, on three cultivars of pepper, Capsicum annuum L., 60 days after the inoculation with 5,000 eggs in a growth chamber

\begin{tabular}{|c|c|c|c|c|}
\hline $\begin{array}{l}\text { Plant species } \\
\text { (Common name) }\end{array}$ & Cultivar & $\mathrm{GI}^{\mathrm{a}}$ & $\mathrm{Pf}^{\mathrm{b}}$ & $\mathrm{Rf}^{\mathrm{c}}$ \\
\hline \multirow[t]{3}{*}{ Capsicum anпиит L. (Pepper) } & Aurelio & 5 & $105720.00 \pm 16534.87 \mathrm{ab}$ & 21.14 \\
\hline & Solero & 5 & $107100.00 \pm 19650.57 \mathrm{ab}$ & 21.42 \\
\hline & Zafiro R2 & 5 & $57840.00 \pm 11076.46 b$ & 11.57 \\
\hline Solanum lycopersicum L. ${ }^{\mathrm{d}}$ (Tomato) & Easypeel & 5 & $139560.00 \pm 65530.05 a$ & 27.91 \\
\hline
\end{tabular}

${ }^{\mathrm{a}} \mathrm{GI}=$ Gall Index (scale 0-5): 5>100 galls per root system

${ }^{\mathrm{b}} \mathrm{Pf}=$ final population density. Data are means of five replicates \pm standard deviation. Means followed by the same letter do not differ significantly at $P>0.05$, according to Kruskal-Wallis test

${ }^{\mathrm{c}} \mathrm{Rf}$ (reproduction factor) $=\mathrm{Pf} /$ initial inoculum

${ }^{\mathrm{d}}$ Tomato Easypeel was used as a control

pepper cvs Aurelio and Solero were resistant or poor or non-hosts (Ibrahim et al. 1993) to M. hispanica.

Many species of Meloidogyne are known to infect potato and cause significant losses. In Portugal, only M. chitwoodi is considered as a quarantine organism but M. hispanica and other Meloidogyne spp. have been found frequently in potato fields (Conceição et al. 2009). Reduced tuber quality has been observed although their exact involvement in reducing potato production has not been determined (Conceição et al.
2009). Cultivars of potato in this experiment were maintained on a mixture of sandy loam soil and sand (1:2), favourable for development of Meloidogyne (Fujimoto et al. 2010), which could explain in part the greater Rf exhibited. Cabbage cv. Bacalan, cauliflower cv. Temporão and pepper cv. Zafiro R2 were all considered as hypersusceptible to $M$. hispanica, a term proposed by Canto-Sáenz (1985) instead of "intolerant", to indicate a non-efficient host that suffers significant damage $(\mathrm{GI}>2)$ despite the nematode not
Fig. 1 DNA amplification products of Capsicum annuum L. cultivars using SCAR_CD and SCAR_B94 linked to the $\mathrm{Mel}$ and $\mathrm{Me} 7$ genes and $\mathrm{Me} 3$ gene, respectively. Lanes: 1-Solero; 2-Zafiro R2; 3-Aurelio; 4Doux Long des Landes; 5Yolo Wonder; 6-DH330; 7 DH149; C-negative control; M- DNA marker (HyperLadder II, Bioline)

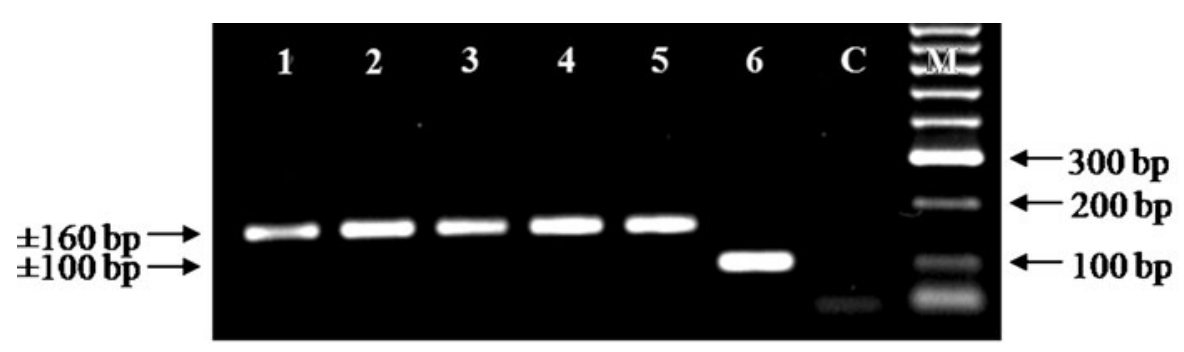

SCAR_CD

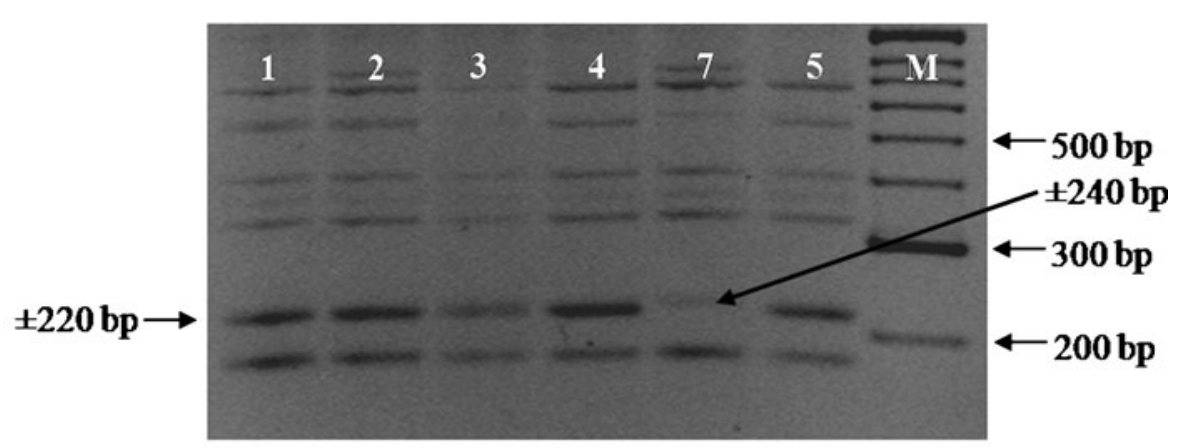

SCAR B94 


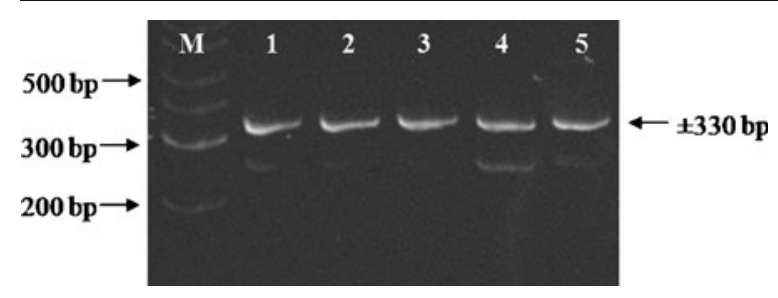

Fig. 2 DNA amplification products of Capsicum annuum L. cultivars using SCAR linked to the $N$ gene. Lanes: 1-Solero; 2Zafiro R2; 3-Aurelio; 4-Doux Long des Landes; 5-Yolo Wonder; M- DNA marker (HyperLadder II, Bioline)

actually reproducing $(\mathrm{Rf}<1)$ on them, or a poor host accordingly to Ibrahim et al. (1993). Lettuce cv. Esperie was found susceptible to $M$. hispanica in the present study despite previously reported as hypersusceptible (Maleita et al. 2005). Furthermore, pepper cv. Zafiro R2 was considered hypersusceptible while had been previously reported as resistant (Maleita et al. 2005).

Root-knot nematode species, with limited host range, such as M. graminis, M. naasi, M. partityla, M. ichinohei and $M$. kralli can be managed by crop rotations (Karssen and Moens 2006). Our findings showed that $M$. hispanica is a highly polyphagous species with a wide host range, similar to $M$. arenaria, M. hapla, M. incognita and M. javanica, that include plants in several botanical families, suggesting that there are very few chances for the control of this nematode by crop rotation. Consequently, it would be wise to avoid susceptible crops in areas known to be infested with this nematode, being essential to take all measures available to limit the spread of $M$. hispanica from infested to non-infested areas. If susceptible plants are consecutively planted in the same field, the nematode population will increase to levels that will affect plant growth and crop quantity and quality. Only the resistant pepper cvs Aurelio and Solero appear to be suitable as rotation crops for management of M. hispanica populations. These cultivars could be included in rotation in areas where crops highly susceptible to this nematode are currently grown, and so help to reduce nematode population density and prevent possible losses due to M. hispanica. Previous studies have shown that the use of non-host, immune or resistant crops, for example grasses, barley and marigold, was highly effective in controlling populations of Meloidogyne species. However, for farmers, crop rotation including non-host plant species does not always fit with intensive agricultural practices and also may require high investment in machinery and cultural practices while such crops may not be profitable in markets (Wesemael et al. 2011). Furthermore, the duration of resistance in non-host plant species and cultivars can be limited by the breaking of resistance due to changes in environmental conditions and/or the selection to virulence by continuous exposure of the particular nematode species to resistant plants (Dropkin 1969; Jarquin-Barberena et al. 1991).

Meloidogyne hispanica could reproduce on ten heterozygous tomato genotypes (Mimi) and nine homozygous (MiMi) for the Mi- 1 locus as identified using the marker REX-1, with all these tomato genotypes being excellent or good hosts, except one (genotype Rapit, Mimi) (Maleita et al. 2011b). In the present study, the highest reproduction values were recorded at $29.3 \pm 1.8^{\circ} \mathrm{C}$ and $33.6 \pm 1.2^{\circ} \mathrm{C}$ for the $\mathrm{Mi}-1$ resistant tomato cv. Rossol. At $24.4 \pm 8.2^{\circ} \mathrm{C}$ and $25 \pm 2.7^{\circ} \mathrm{C}$, the inability of the nematodes to reproduce at the same levels on the resistant tomato cv. Rossol as on susceptible cv. Easypeel suggests an incomplete virulence of the nematode or that the resistant cultivar retain some of their capability to limit nematode development and reproduction (Ornat et al. 2001). At $33.6 \pm 1.2^{\circ} \mathrm{C}$, the plants of tomato cv. Easypeel died before the end of the experiment, due to the high and constant temperature regime which is probably unfavourable for the growth of this cultivar.

Resistance was shown for the pepper cultivars Aurelio, Solero and Zafiro R2 at all temperatures tested. The results obtained with SCAR_CD and SCAR_B94 markers and the marker linked to the $N$ gene indicated the absence of the $\mathrm{Mel}, \mathrm{Me} 3, \mathrm{Me} 7$ and $\mathrm{N}$ genes on these pepper cultivars. Thus, the resistance to $M$. hispanica may be conditioned by $\mathrm{Me} 2, \mathrm{Me} 4, \mathrm{Me} 5$ and Me6 genes or other unidentified genes stable at high soil temperatures. At least for these pepper cultivars, high temperature may not be a critical factor for the expression of resistance, which may remain effective in the tropic and warm climates. However, the resistance conferred by the peppers cvs. Aurelio, Solero and Zafiro R2 to M. hispanica reproduction was found to be partial and a proportion of nematodes were able to reproduce. The selected M. hispanica isolate, obtained from plants of cv. Aurelio subjected to $33.6 \pm 1.2^{\circ} \mathrm{C}$, was able to reproduce on the three pepper cultivars when tested at $25 \pm 2{ }^{\circ} \mathrm{C}$, thus breaking their resistance. The variation in reproduction $(\mathrm{Pf})$ among the pepper cultivars and across replicated 
plants within cultivars, suggests that the original isolate of M. hispanica was a mixture of virulent and avirulent individuals. This also may explain the different reaction of cv. Esperie of lettuce and cv. Zafiro $\mathrm{R} 2$ of pepper between experiments. The durability of the resistance depends on the frequency of virulent individuals within the particular local population and the continuous exposure of the resistant plants to the nematode (Sorribas et al. 2005). Therefore, it will be important to monitor the performance of these cultivars against local populations of the nematode and assess their potential for use in infested soils, because different populations of the same species of Meloidogyne can react differently on the same plant species/cultivar. Moreover, their use over long periods of time may result in the selection of virulent $M$. hispanica isolates able to overcome the resistance. Pepper cultivars can be an alternative to M. hispanica control because they provides a high level of nematode suppression. However, resistant cultivars should be used in an integrated management context in combination with other control measures, such as nematicides, fallow periods and solarisation or included in crop rotation schemes.

Acknowledgements This research was supported by FEDER funds through the "Programa Operacional Factores de Competitividade - COMPETE" and by national funds through FCTFundação para a Ciência e a Tecnologia under the project PTDC/AGR-AAM/103873/2008. Carla Maleita was supported by a FCT-MCTES grant (SFRH/BD/24275/2005). The authors would like to thank Dr. Caroline Djian-Caporalino from INRA, Unité Interactions Biotiqes et Santé Végétale (IBSV), France, for the helpful comments and suggestions and for providing the seeds of the pepper accessions Yolo Wonder, Doux Long des Landes, DH149 and DH330 and Germiplanta - Viveiros de Plantas Lda., Portugal and Pioneer Hi-Bred Sementes de Portugal, S.A., Portugal, for providing some plants and seeds. Rothamsted Research receives grant aided support from the Biotechnological and Biological Sciences Research Council of the United Kingdom.

Open Access This article is distributed under the terms of the Creative Commons Attribution Noncommercial License which permits any noncommercial use, distribution, and reproduction in any medium, provided the original author(s) and source are credited.

\section{References}

Abrantes, I. M. de O., Vieira dos Santos, M. C., Conceição, I. L. P. M. da, Santos, M. S. N. de A., \& Vovlas, N. (2008). Root-knot and other plant-parasitic nematodes associated with fig trees in Portugal. Nematologia mediterranea, 36, 131-136.
Byrd, D. W., Kirkpatrick, T., \& Barker, K. R. (1983). An improved technique for clearing and staining plant tissues for detection of nematodes. Journal of Nematology, 15, 142-143.

Canto-Sáenz, M. (1985). The nature of resistance to Meloidogyne incognita (Kofoid \& White, 1919) Chitwoodi, 1949. In J. N. Sasser \& C. C. Carter (Eds.), An advanced treatise on Meloidogyne. Vol. I. Biology and control (pp. 225231). Raleigh: North Carolina State University Graphics.

Carneiro, R. M. D. G., Almeida, M. R. A., \& Gomes, A. C. M. M. (2004). First record of Meloidogyne hispanica Hirschmann, 1986 on squash in State of Bahia, Brazil. Nematologia Brasileira, 28, 215-218.

Castillo, P., Gutiérrez-Gutiérrez, C., Palomares-Rius, J. E., Cantalapiedra Navarrete, C., \& Landa, B. B. (2009). First report of root-knot nematode Meloidogyne hispanica infecting grapevines in Southern Spain. Plant Disease, 93, 1353 .

Chaves, A., Melo, L. J. O. T., Simões Neto, D. E., Costa, I. G., \& Pedrosa, E. M. R. (2007). Declínio severo do desenvolvimento da cana-de-açúcar em tabuleiros costeiros do Estado de Pernambuco. Nematologia Brasileira, 31, 93-95.

Cofcewicz, E. T., Carneiro, R. M. D. G., Randig, O., Chabrier, C., \& Quénéhervé, P. (2005). Diversity of Meloidogyne spp. on Musa in Martinique, Guadeloupe and French Guiana. Journal of Nematology, 37, 313-322.

Conceição, I. L. P. M. da, Cunha, M. J. M. da, Feio, G., Correia, M., Vieira dos Santos, M. C., Abrantes, I. M. de O., \& Santos, M. S. N. de A. (2009). Root-knot nematodes, Meloidogyne spp., on potato in Portugal. Nematology, 11, 311-313.

Djian-Caporalino, C., Fazari, A., Arguel, M. J., Vernie, T., Vande Casteele, C., Faure, I., Brunoud, G., Pijarowski, L., Palloix, A., Lefebvre, V., \& Abad, P. (2007). Root-knot nematode (Meloidogyne spp.) Me resistance genes in pepper (Capsicum annuиm L.) are clustered on the P9 chromosome. Theoretical and Applied Genetics, 114, 473-486.

Dropkin, V. H. (1969). The necrotic reaction of tomatoes and other hosts resistant to Meloidogyne: reversal by temperature. Phytopathology, 59, 1632-1637.

Esbenshade, P. R., \& Triantaphyllou, A. C. (1985). Use of enzyme phenotypes for identification of Meloidogyne species. Journal of Nematology, 17, 6-20.

Fargette, M. (1987). Use of the esterase phenotype in the taxonomy of the genus Meloidogyne. 2. Esterase phenotypes observed in West African populations and their characterization. Revue de Nématologie, 10, 45-56.

Fujimoto, T., Hasegawa, S., Otobe, K., \& Mizukubo, T. (2010). The effect of soil water flow and soil properties on the motility of second-stage juveniles of the root-knot nematode (Meloidogyne incognita). Soil Biology \& Biochemistry, 42, 1065-1072.

Hirschmann, H. (1986). Meloidogyne hispanica n. sp. (Nematoda: Meloidogynidae), the "Seville Root-Knot Nematode". Journal of Nematology, 18, 520-532.

Hugall, A., Moritz, C., Stanton, J., \& Wolstenholme, D. R. (1994). Low, but strongly structured mitochondrial DNA diversity in root knot nematodes (Meloidogyne). Genetics, 136, 903-912.

Hussey, R. S., \& Barker, K. R. (1973). A comparison of methods of collecting inocula of Meloidogyne spp., including a new technique. Plant Disease Reporter, 57, 1025-1028. 
Ibrahim, I. K. A., Lewis, S. A., \& Harshman, D. C. (1993). Host suitability of Graminaceous crop cultivars for isolates of Meloidogyne arenaria and M. incognita. Supplement to Journal of Nematology, 25, 858-862.

Jarquin-Barberena, H., Dalmasso, A., de Guiran, G., \& Cardin, M.-C. (1991). Acquired virulence in the plant parasitic nematode Meloidogyne incognita. I. Biological analysis of the phenomenon. Revue Nématologie, 14, 261-275.

Karssen, G. (2004). Nieuwe wortelknobbelaaltjes en opvallende waarnemingen in Europa. Gewasbescherming, 5, 245-246.

Karssen, G., \& Moens, M. (2006). Root-knot nematodes. In R. N. Perry \& M. Moens (Eds.), Plant nematology (pp. 5990). Wallingford: CABI.

Karssen, G., \& van Hoenselaar, T. (1998). Revision of the genus Meloidogyne Göldi, 1982 (Nematoda: Heteroderidae) in Europe. Nematologica, 44, 713-788.

Kleynhans, K. P. N. (1993). Meloidogyne hispanica Hirschmann, 1986 and M. ethiopica Whitehead, 1968 in South Africa (Nemata: Heteroderidae). Phytophylatica, 25, 283-288.

Landa, B. B., Palomares Rius, J. E., Vovlas, N., Carneiro, R. M. D. G., Maleita, C. M. N., Abrantes, I. M. de O., \& Castillo, P. (2008). Molecular characterization of Meloidogyne hispanica (Nematoda, Meloidogynidae) by phylogenetic analysis of genes within the rDNA in Meloidogyne spp. Plant Disease, 92, 1104-1110.

Maleita, C. M., Vieira dos Santos, M. C., \& Abrantes, I. M. de O. (2005). Resistência de plantas cultivadas ao nemátodedas-galhas-radiculares Meloidogyne hispanica. In A Produção Integrada e a Qualidade e Segurança AlimentarActas do VII Encontro Nacional de Protecção Integrada. (pp. 277-283). Edições IPC: Coimbra, Portugal.

Maleita, C. M., Curtis, R. H. C., \& Abrantes, I. M. de O. (2011a). Thermal requirements for the embryonic development and life cycle of Meloidogyne hispanica. Plant Pathology, (in press).

Maleita, C. M., Vieira dos Santos, M. C., Curtis, R. H. C., Powers, S. J., \& Abrantes, I. M. de O. (2011b). Effect of the $M i$ gene on reproduction of Meloidogyne hispanica on tomato genotypes. Nematology, 13, 929-939.

Ornat, C., Verdejo-Lucas, S., \& Sorribas, F. J. (2001). A population of Meloidogyne javanica in Spain virulent to the $M i$ resistance gene in tomato. Plant Disease, 85, 271-276.
Sasser, J. N., Carter, C. C., \& Hartman, K. M. (1984). Standardization of host suitability studies and reporting of resistance to Root-knot nematodes. Raleigh: North Carolina State Graphics.

Sorribas, F. J., Ornat, C., Verdejo-Lucas, S., Galeano, M., \& Valero, J. (2005). Effectiveness and profitability of the Miresistant tomatoes to control root-knot nematodes. European Journal of Plant Pathology, 111, 29-38.

Taylor, A. L., \& Sasser, J.N. (1978). Biology, identification and control of root-knot nematodes (Meloidogyne spp.). A cooperative publication of the Department of Plant Pathology, North Carolina State University and the United States Agency for International Development, Raleigh: North Carolina State University Graphics.

Thies, J. A., Dickson, D. W., \& Fery, R. L. (2008). Stability of resistance to root-knot nematodes in "Charleston Belle" and "Carolina Wonder" bell peppers in a sub-tropical environment. HortScience, 43, 188-190.

Trudgill, D. L., Bala, G., Blok, V. C., Daudi, A., Davies, K. G., Gowen, S. R., et al. (2000). The importance of tropical root-knot nematodes (Meloidogyne spp) and factors affecting the utility of Pasteuria penetrans as a biocontrol agent. Nematology, 2, 823-845.

van der Wurff, A. W. G., Janse, J., Kok, C. J., \& Zoon, F. C. (2010). Biological control of root knot nematodes in organic vegetable and flower greenhouse cultivation, Report of a study over the period 2005-2010. Bleiswijk: Wageningen UR Greenhouse Horticulture.

Wang, D., \& Bosland, P. W. (2006). The genes of Capsicum. HortScience, 41, 1169-1187.

Wang, L. H., Gu, X. H., Hua, M. Y., Mao, S. L., Zhang, Z. H., Peng, D. L., Yun, X. F., \& Zhang, B. X. (2009). A SCAR marker linked to the $N$ gene for resistance to root knot nematodes (Meloidogyne spp.) in pepper (Capsicum annuum L.). Scientia Horticulturae, 122, 318-322.

Wesemael, W. M. L., Viaene, N., \& Moens, M. (2011). Rootknot nematodes (Meloidogyne spp.) in Europe. Nematology, 13, 3-16.

Zhang, Y., Uyemoto, J. K., \& Kirkpatrick, B. C. (1998). A small-scale procedure for extracting nucleic acids from woody plants infected with various phytopathogens for PCR assay. Journal of Virological Methods, 71, 45-50. 